\title{
Integrating knowledge and employer brand management: A conceptual model
}

Joanna Krywalski Santiago, ISEG - Lisbon School of Economics and Management, Universidade de Lisboa, Portugal, joannas@iseg.ulisboa.pt

\begin{abstract}
The purpose of this paper is to propose an integrated framework of the deep-rooted knowledge management and the steadily growing field of employer brand management. Additionally, this paper intends to examine the connections between knowledge management, organizational learning and branding and identifies the factors that affect the employees' perceptions and commitment towards their organizational brands. Finally, it reviews the mechanisms that guide the processes and outcomes of knowledge and brand performance. The proposed model is based on the synthesis of knowledge and marketing literature. The method used in this study is a narrative literature review based upon 114 articles collected and analyzed for this revision. The proposed model makes an original contribution to knowledge and marketing management by encompassing the conceptual and practical limitations and by interconnecting the two fields creating an opening for new interdisciplinary studies. Consequently, this study brings several practical implications into existing literature: 1) it enhances the application of knowledge and brand management practices; 2) it provides a comprehensive conceptual framework; 3) it increases organizational understanding of how to motivate sought employee brand-related actions through the process of organizational learning and knowledge circulation.
\end{abstract}

Keywords: Knowledge management, organizational learning, brand management, employer brand, employee-based brand equity.

\section{Introduction}

It is widely recognized that knowledge management is essential for gaining positional advantage and organizational performance (Swanson \& Holton, 2001). Similarly, that brand management enables the value creation and superior performance (Balmer et al., 2001). Particularly, the employer branding considers the employees' talent and commitment to their organizational brand, as the factors that can determine organizational success. Indeed, with the current technological growth, organizations are overlooking a constant requirement for knowledge sharing among talented employees. Up to date, it appears that there are limited studies linking the fields of knowledge and marketing management. However, a recent study by Zebal et al. (2018) have proposed a theoretical model integrating the explicit marketing activities and knowledge (the internal knowledge perspective) with tacit knowledge and external marketing (the external knowledge perspective). With similarity to this study, the model proposed by Zebal et al. (2018) was based on the synthesis of existing knowledge and marketing literature and made an important contribution to theoretical and practical 'marketing management knowledge'. By doing so, Zebal 
et al. (2018) contributed to holistic market orientation from a knowledge management standpoint. Additionally, the proposed framework exhibited the necessity for a company to create knowledge considering the needs and wants of employees and to disseminate the created knowledge across the company. The model also emphasized the significance of employee-contributed knowledge and suggested that to seek success, a company must "create, capture, disseminate and apply knowledge" (Zebal et al., 2018, p. 7). According to Zebal et al. (2018), if a company forms internal marketing agendas, and at the same time empowers and trains its employees with suitable knowledge, it will significantly improve the employees' commitment and productivity, which subsequently will impact the overall organizational success. Respectively, Zebal et al. (2018) suggested that there is a demand to understand how marketing management knowledge affects the success of a company. This opens a door to a new interdisciplinary discussion.

The main research objective of this investigation focuses on conjoining the knowledge and brand management into one comprehensive framework which will focus on employer brand and the employee response (commitment, satisfaction, \& engagement). Whilst linking the two areas, it is essential to understand the processes that contribute to the knowledge circulation and organizational learning, their impact on employer brand and employee perceptions, while finally on the organizational outcomes of knowledge and brand performance.

This paper links knowledge and brand management in presenting a narrative literature review across the two disciplines with the aim of briefly summarizing the body of knowledge (BOK), current research, while highlighting their significance and identifying possible gaps. Subsequently, the main objective of this study is to provide a comprehensive background and to propose a new conceptual model combing the two perspectives, therefore, preparing the terrain for future investigation. The main difficulty of this study is indeed the systematization of the two distinctive fields that have not been linked in too many studies up to date. Due to this, fact the present review is of a narrative and not systematic nature.

According to Cronin at al. (2008), a well-defined research question is fundamental before undertaking a literature review. The research question guiding this study is: can the fields of knowledge and brand management be integrated into a comprehensive framework?

Based on those premises this study has three main objectives:

1. To list the underlying theories and summarize briefly the main concepts in the fields of knowledge management and brand management.

2. To display the linkage between knowledge and brand management, while considering the importance of knowledge and learning' among employees in the process of creating knowledge and brand performance.

3. To propose a conceptual model linking the two fields of research that can serve as a guide for future empirical research.

\section{Theoretical Background}

There are a few dominant theories underlying this research and giving the roots for both knowledge and brand management. First, the Research-Based View (RBV) of the firm, which still resides as basis for examining strategic management (Barney et al., 2001). RBV and 'resource-based theory' 
state that firm' capabilities and resources are a source of its long-term strategy and can lead to positional advantage (Grant, 1991). Barney et al. (2001) based their study on a previous work (Barney et al., 1991) and suggested that those firm's resources and capabilities can be perceived as "bundles of tangible and intangible assets, including a firm's management skills, its organizational processes and routines, and the information and knowledge it controls" (Barney et al., 2001, p. 625). Similarly, the RBV has brought significant advances in the area of Human Resource Management (HRM), emphasizing the importance of employees and their capabilities to a firm's success (Barney et al., 2001). RBV supports the employer branding on the assumption that assumption that human capital brings value to the firm, and through skillful investment in human capital, firm performance can be enhanced (Backhouse \& Tikko, 2004, p. 503).

According to Moingeon and Edmondson (1996), the importance of organizational learning resists preliminarily on the RBV, as the knowledge and skills can be considered as the intangible resources and the collective knowledge can become a source of profits and superior performance. Such resources as know-how, routines, and experiences are a foundation of organizational capabilities (Barney, 1991). Originating from RBV, the Knowledge-Based View (KBV) also provides a strong theoretical support for organizational learning (Cabrera-Suárez et al., 2001). In order to perform well, firm needs the tacit knowledge to integrate its capabilities and resources. According to Cabrera-Suárez et al. (2001), "the knowledge-based approach of a firm tries to analyze how organizations create, acquire, apply, protect, and transfer knowledge" (p. 39). This progression from resource-based-view to knowledge-based-view has reinforced the importance of organizational learning (Imran et al., 2016). Indeed, in current unpredictable business environment, organizational learning can be perceived as a foundation of competitive advantage. Undeniably, organizations that absorb the knowledge faster are able to address their organizational problems more rapidly, and therefore, it becomes easier for them to sustain their position in the industry (Imran et al., 2016). Additionally, a continuous learning within organization has positive consequences as it comes to human resources, especially in the areas of employee motivation, commitment and performance. In their study on the effect of organizational climate on knowledge management, Chen and Huang (2007) claimed that human resource practices and organizational climate are crucial to influence and shape the attitudes and behavior of individuals. Basing on those premises, it can be indicated that the knowledge management and organizational learning may influence the relationship between human resources and firms' performance.

The role of employer and organizational learning can be analyzed in the light of two complementary theories explaining social identity: Social Identity Theory (SIT) and SelfCategorization Theory (SCT). SIT emphases the role of self-conception, rational attitudes, and beliefs in intergroup relations (Abrams \& Hogg, 1990). From its formulation in the early 1970s (Tajfel, 1970), the belief of SIT is that group behavior results from from a sense of group membership, meaning that the groups give a sensation of social identity and belonging. SCT accepts that individuals differ in their readiness to join a group based on their individual fit and the group's accessibility. According to Korte (2007), "in the process of categorization, individuals evaluate the accessibility of a group for them and, in turn, are assessed by the group for readiness and fit; one's history, personality, status, and opportunity constrain the choice of groups available" (p. 169). SIT explains the individual movements in "social settings" - such as organizations or workgroups (Korte, 2007; Maxwell \& Knox, 2009). Additionally, "through the process of self- 
categorization, the individual constructs the meaning of this social identity" (Korte, 2007, p.169). The SIT is particularly important for the organizations, as it can deeply affect individual learning, attitudes and performance (Korte, 2007). From the employee perspective, the social identity will also influence the employee satisfaction, loyalty, and commitment ( $\&$ as a result - a firm performance) (Maxwell \& Knox, 2009).

Those theories are often studied together and known as the 'Social Identity Approach to Organizational Identification' (SIA) (Maxwell \& Knox, 2009). Given that organizational identification has been found to enrich behavior that supports the corporate brand and engage employees in organizational citizen behavior, SIA offers useful guidelines to study employer brand. Additionally, from the SIA perspective, organizational identity seems to correspond conceptually to employer brand image (Maxwell \& Knox, 2009). Suitably, the employees feel the 'fit' with their organization when they recognize its attractiveness and uniqueness. Therefore, Maxwell and Knox (2009) assume that a unique and attractive employer brand, as described in the context of SIA, can inspire employees to "live the brand" (p. 5).

\section{Methodology}

According to Cronin at al. (2008), a narrative literature review traditionally tends to summarize existing literature while analyzing the relevant studies in the subject area. This type of review tends to summarize and critique a body of literature, in a way so it is possible to draw conclusions about the topic under investigation (Cronin et al., 2008). The literature review consists of the principal studies in the subject area and is selective in the choice of material. Its main objective is to join the literature on a specific subject and to synthesize it. In agreement with Cronin et al. (2008), the narrative literature review process consists of few steps: 1) selecting a review topic - where it is advisable to refine it further and state a clear research question as well as research objectives; 2) searching the literature - with the aim to identify, in an organized way, the relative information; 3) gathering, reading, and analyzing the literature - which initially involves classification of the articles based on abstracts, fields of research, and then undertaking a systematic as well as critical review of the content; 3 ) writing the review - presenting the findings.

Although a narrative is not identical to a systematic review, its objectives are quite similar (Cronin et al., 2008). The most common technique of identifying literature in narrative review are the keyword searches. For this study, alternative keywords with similar meanings were considered with the attempt to prompt further information. Some of these alternative keywords were generated by the databases' thesaurus. Additionally, Boolean operators, such as 'AND', 'OR', and 'NOT' were used to combine keywords. With the aim of identifying the links between the two areas, a special attention was dedicated to studies on knowledge management with a reference to employees, and to articles on employee branding that refer knowledge management.

Accordingly, this study briefly summarizes the extent search in Google Scholar and Web of Science. Based on the search in the Web of Science, it was determined that the term 'Knowledge Management' (KM) counts with 170,334 records in this database. The main areas of investigation focusing on KM are: 'management' with 21,943 records (around 13\% of all the studies conducted), followed by 'computer science information systems' counting with 12,839 studies (7,5\%), 
business with 11,542 records (around 7\%), 'environmental sciences' with 9,568 records (approx. $6 \%$ of all the studies). As for the 'Brand Management' (BM), the database consists of 6,590 records with such areas as: 'business' with 2,275 records (approx. 35\%), 'management' with 1,826 records (28\%), 'hospitality, leisure, sport and tourism' with 559 records (8,5\%). Based on the search in the Web of Science, it was determined that the term 'Employer Brand' (EB) counts only with 387 entrances. The main areas of investigation focusing on EB are: 'management' with 140 counts, and 'business' with 119 counts.

It is worth mentioning that the oldest reference used in this paper is related to KM and dates as far back as the 1970s (March \& Olsen, 1975), while concept of employer brand appeared to be introduced initially by Ambler and Barrow in 1996, and employee-based brand equity concept appear to be introduced as early as in 2009 (King \& Grace, 2009). In total, over 100 articles on knowledge and brand management were analyzed as well as directly referenced. The databases indicate also the growing interest in the field of KM and its increasing multi-dimensionability. Nonetheless, not too many studies linking knowledge and brand management have been found, and those existing, represent a wide spectrum of different perspectives.

To categorize the factors linking knowledge and brand management, this paper included articles not only on knowledge or brand management, but also on topics related to organizational learning, employer brand, employee engagement, employee role clarity, organizational and brand commitment, job satisfaction, employer brand attractiveness and equity, as well as knowledge and brand performance. All of the topics related to employer brand are logically connected and belong to the relatively new 'third perspective' of brand equity - proposed by King and Grace (2009), while denominated as 'employee-based brand equity'.

The literature review begins by defining KM, attempting to cover briefly the main schools of thought in the area. Then, the organizational learning is defined, and a summary is included of the four processes related to organizational learning: knowledge acquisition, information distribution, information interpretation and organizational memory. A definition of organizational unlearning is provided, which seems to be crucial for the organizational renewal. Finally, the literature review passes to the field of brand management and the issues related to employer brand as well as employee-based brand management. The literature review ends with a proposition of a new conceptual framework that links the knowledge and brand management.

\section{Literature Analysis and Synthesis}

\section{Knowledge Management}

KM was defined as "a conscious strategy for moving the right knowledge to the right people at the right time, to ... improve organizational performance" (O’Dell \& Grayson, 1998, p. 155). O'Dell and Grayson (1998) suggested also that KM is a process of "identifying, capturing, and leveraging knowledge to help the company compete" (p. 154). Accordingly, KM gained its importance as one of the factors facilitating an organization to gain a positional advantage and to achieve high levels of performance. Correspondingly, Dimitriades (2005) defined KM "as the management discipline concerned with the systematic acquisition, creation, sharing and use of knowledge in organizations, aiming to improve a firm's competitiveness via continuous, rapid innovation" (p. 
319). Dimitriades (2005) mentioned that the employees' explicit and tacit knowledge is shared through collaboration and in this way becomes available to the whole organization.

In his study, Nonaka (1994) introduced the fundaments of a theory of organizational knowledge creation and stated that any organization, in a way to adapt to a changing environment, must generate information and knowledge. Also, Grant (1991) stated that organizations are responsible for integrating the knowledge of their members. Szulanski (1996) stated that the capacity to allocate internally the best practices is crucial to build competitive advantage. All of the mentioned authors link the knowledge management with innovation as a mode of gaining positional advantage. Interestingly, none of the above alleged the importance of corporate brand, known to be one of the predictors of a company's value (both in financial \& non-financial terms). This concern is essential for service companies which due to their characteristics (mainly intangibility \& inseparability) face special challenges in pursuing knowledge (Storey \& Kahn, 2010). According to the knowledge-based view of the firm, organizational success is influenced by the "capability of organizations to develop new knowledge-based assets that create core competencies" (Pemberton \& Stonehouse, 2000, p. 184). They claimed that organizational learning is an essential when an organization tends to use its knowledge resources to generate superior performance (Pemberton \& Stonehouse, 2000). Therefore, there is a strong relationship between knowledge management and organizational learning, as "successful learning organizations create an organizational environment that combines organizational learning with knowledge management" (Pemberton \& Stonehouse, 2000, p. 186). Similarly, Dimitriades (2005) in her study focusing on creating strategic capabilities in the new economies, examined the relationship between KM and organizational learning. She claimed that an organization pursuing its objectives and goals must implement organizational learning followed by changes in its organizational behavior (p. 320).

\section{The Knowledge Management Process}

The first component of KM process, also called by Lee et al. (2005) a 'knowledge circulation process', means the knowledge creation which conveys tacit and explicit knowledge as well as encourages relations among individuals. Knowledge creation is measured by employee's tasks understandings and information understandings. Nonaka et al. (1996) proposed a theory of organizational knowledge creation and described it as "the process that organizationally amplifies the knowledge created by individuals and crystallizes it as part of the knowledge system of an organization" (p. 883). In 2015, Nonaka and Toyama made an attempt to build a new knowledgebased theory of the firm and organization to explain the dynamic process of knowledge creation as well as utilization, in which they conceptualized the knowledge creation as a dialectical process with many contradictions emerging as a result of interactions among individuals, organization and the environment. They claimed that the ability to create and utilize the knowledge within an organization, is important to achieve superior competitive advantage (Nonaka \& Toyama, 2015).

Knowledge accumulation is the second component of the KM process and accordingly to it all employees must have access to the relevant knowledge to assist in their work and decision making (Lee et al., 2005). According to Lee et al. (2005), knowledge gathered in organizations can play a critical role in improving organizational performance by eliminating obstacles. However, it is 
important to notice that the knowledge to be beneficial for the decision-making process, should be accumulated systematically.

The third component of KM process is knowledge sharing, which "promotes diffusion of knowledge and contributes to making the work process astute and knowledge-intensive" (Lee et al., 2005, p. 472). As a result, the employees start to consider themselves as 'knowledgeable' and they are able to apply the knowledge into their work functions. One of the studies (McDermott \& O'Dell, 2001) reflected the problem of overcoming the cultural barriers to sharing knowledge: They claimed that most of the organizations adopt their KM to fit their culture, instead of changing their culture to balance the tasks of their KM. As such, they claimed that knowledge sharing involves "balancing the visible and invisible dimensions of culture - visibly demonstrating the importance of sharing knowledge and building on the invisible core values" (McDermott \& O'Dell, 2001, p. 84).

Knowledge utilization, the fourth component of KM process, can occur at all levels of management activities in organizations (Lee et al., 2005). Interestingly, Duncan (1972) related the concept of knowledge flow to management education and development, which can influence knowledge utilization. One of the common practices of knowledge utilization is to embrace the best practices from different organizations and try to apply them (O'Dell \& Grayson, 1998).

The fifth component of the KM process is knowledge internalization, which may occur when individual workers discover relevant knowledge, obtain it and then apply it (Lee et al., 2005). Consequently, internalization may generate the new knowledge and provides a basis for active knowledge creation. According to Chirico and Salvato (2016), knowledge internalization "denotes collective ability to recognize (identify and value), assimilate (understand), and exploit (build on and use) each other's knowledge", therefore it "requires team members to not only be competent in their individual areas, but also to be familiar with other team members' expertise and skills" (p. 6). Additionally, in distinction from knowledge sharing and knowledge transfer, which focus on knowledge dissemination, internalization highlights the "absorption of relevant knowledge by team members and its collective use" (Chirico \& Salvato, 2016, p. 6).

In addition to those components of KM process, organizations shall support the arrangement of other factors, such as the infrastructure, new and existing knowledge acquisition, as well as knowledge distribution and blending (Lee et al., 2005).

\section{Knowledge Performance}

Knowledge can be considered in two ways: (1) as contributions to a production process; and (2) as outcomes of a KM (Postrel, 2002). Knowledge performance is the result of KM and describes its outcomes. More accurately, the term "knowledge performance" indicates the knowledge generated inside the organization (as a result of learning, information distribution \& integration, etc.), while used to generate new products and services that improve the firm's competitive position. It is essential to notice that knowledge performance means more than new product development (Pertusa-Ortega et al., 2010). Measuring knowledge performance is crucial for the organization to verify if the KM processes are bringing adequate results and to correct the used methods when the level of performance is low. 


\section{Defining Organizational Learning}

Organizational learning remines a subject of investigation in a variety of academic disciplines. For many years the terms 'organizational learning' and 'learning organization' were used uniformly, while nowadays they are differentiated and considered as a distinct phenomenon. Organizational learning is habitually entitled as a 'process' and the learning organization is considered as an 'entity'. Dimitriades (2005) stated that a learning organization can be considered a strategic goal and organizational learning serves as a mean to achieve this goal. Pedler et al. (1991) defined a learning organization as "one which facilitates the learning of all of its members and continuously transform itself" (p. 3). Consequently, the concept of learning organization emphases on the organizations projected to facilitate the learning of their members (Coopey, 1995).

Conflating the terminology, many conceptualizations of organizational learning exist. Since being addressed as a feature of the theory of the firm (Cyert \& March, 1963), in the organizational theory (Weber, 1991), and in the 'dynamic capabilities' theory of strategic management (Teece et al., 1997), the concept developed as being associated with increased innovativeness (Dogson, 1993), new product development (Imai et al., 1985) as a key to competitiveness and strategic advantage (Garratt, 1987; Namada, 2018). Emphasizing the continuously changing nature of organizations, learning is also considered to be a 'dynamic concept' that can combine different levels of analysis (Dogson, 1993). In the more recent studies, organizational learning is linked with Information Technology (IT) skills and IT (Cha et al., 2008), considered a key element of value creation in knowledge-based management (North \& Kumta, 2018) and a determinant factor in environmental strategies (Fraj et al., 2015).

In a more recent work, Hanaysha (2016) tested the effects of work engagement, organizational learning, and work environment on organizational commitment. The results suggested that organizational learning can be reflected as one of the key factors in forecasting employee commitment toward the organization and, therefore, organizations should focus on organizational learning and guarantee the existence of a learning culture among the employees. As the field of organizational learning has many conceptualizations, it has been also covered with a variety of definitions. Some of those definitions take a narrow approach. For instance, the definition of Fiol and Lyles (1985) is taking a problem-solving approach and explains the organizational learning as "the process of improving actions through better knowledge and understanding" (p. 803). They suggested that despite the different approaches into studying the organizational learning, a consensus exists as it comes to the significance of environmental alignment, the distinction between organizational and individual learning and finally, while considering the key factors influencing the learning process, such as the organizational culture or strategy. They also stress the importance of organizational alignment to the environment in a constant search of innovation, but they do not explain if that alignment should be rather internal or external (Fiol \& Lyles, 1985).

Whilst it comes to the distinction between organizational and individual learning, some scholars (ex. Dogson, 1993; March \& Olsen, 1975) focused on individual level and claim that most learning in organizations happens at the individual level, while others (ex. Duncan \& Weiss, 1979) criticized the individual approach and focus on the process of creating knowledge as a result of existing 'relationships'. Duncan and Weiss (1979) claimed that organizational members have to engage and interact to develop shared mental models. 
According to Örtenbald (2001), in the 1990s the organizational learning literature became influenced by a social approach to learning, forming a domain of a 'new organizational learning'. In agreement with this perspective, learning is rather a participation than an acquisition of information. Consequently, the "new" organizational learning is collective, and the knowledge is not storable. Nicolini and Menzar (1995) suggested that the perception of organizational learning should be extended in order to stimulate a greater acceptance of the concept. In their study of the social construction of organizational learning, they offered a broader conceptualization and consider the importance of the processes associated with knowledge acquisition and experience enhancing in organizations.

Conflating the terminology, it can observe that some literatures tend to examine the outcomes of learning, while the others examine the processes of learning. Undeniably learning encompasses both processes and outcomes. Dogson (1993) described learning as "the ways firms build, supplement and organize knowledge and routines around their activities and within their cultures, and adapt and develop organizational efficiency by improving the use of the broad skills of their workforces" (p. 377). This broad definition proposed by Dogson (1993) combines a number of important assumptions: (1) learning can have positive consequences even though its outcomes are not always positive; (2) although learning is grounded on individual level, the corporate and group culture are influenced by individual learning; and (3) learning transpires throughout all the activities of the firm.

\section{Constructs and Processes Associated with Organizational Learning}

Huber (1991) provided a broad classification of organizational learning processes and suggests that organizational learning is composed of at least four processes: (1) knowledge acquisition; (2) information distribution; (3) information interpretation, and (4) organizational memory. He highlighted that learning does not always need to be intentional but that "more organizational learning occurs when more of the organization's components obtain this knowledge and recognize it as potentially useful" (Huber, 1991, p. 90).

According to Hubner (1991), knowledge acquisition is "the process by which knowledge is obtain" (p. 90) and relies on the following subconstructs: 'congenital learning' (the inherited knowledge), 'experiential learning' (knowledge acquired through direct experience, both intentional and unintentional), 'vicarious learning' (second-hand experience), 'grafting' (acquiring \& grafting on new members who possess knowledge not previously available within the organization), and finally 'searching and noticing' (scanning, focused search, \& performance monitoring).

Information distribution is defined as "the process by which information from different sources is shared and thereby leads to new information or understanding" (Hubner, 1991, p. 90) and is determinant of the occurrence and scope of learning. It sets on linking information from diverse subunits and "leads the new information and new understanding" (Hubner, 1991, p. 100).

Information interpretation is defined as "the process by which distributed information is given one or more commonly understood interpretations" (Hubner, 1991, p. 90). Information interpretation consists of 'cognitive maps' (belief structures, mental representation, frames of reference - they vary across the organizational units having different responsibilities), 'media 
richness' (crucial for the information to become common), 'information overload' (the excess of the units' capacity to process the information) and 'unlearning' (defined as "a process through which learners discard knowledge" (Hedberg, 1981, p. 18)).

Organizational memory is defined as "the means by which knowledge is stored for future use" (Hubner, 1991, p. 90). It consists of storing and retrieving information and computer-based organizational memory (exchanged electronically across the organization's boundaries).

In a more recent study, Gillani and Kiani (2018) assessed organizational learning processes as predecessors of organizational effectiveness. The results of their study revealed that organizational learning process has a significant effect on organizational effectiveness through mediation of organizational innovation and moderation of work attitude of employees. Based on that, the importance of the role employees play in organizational learning processes can be assumed.

\section{Organizational Unlearning}

Advancing the debate on organizational learning, Nicolini and Menzar (1995) discussed the concept of 'organizational unlearning' and stress the importance of leaving the "old ways of thinking for the new ones" (p. 732). According to them, organizational unlearning is crucial to foster new knowledge and new cognitive frameworks in organizations, although it often meets a general resistance. Organizational unlearning seems to be crucial for the organizational renewal and increase adaptability to changing environments.

Klein (1989) argued that unlearning might bring counter-effects and it is not about "unlearning" but learning from failure. He defined the parenthetic learning as "as the cognitive expulsion of elements from a set" (p. 300) and claims that "parenthetic learning organization is likely to be receptive to its environment, and therefore to input from an organizational analyst" (Klein, 1989, p. 304).

Based on the literature review, it is evident that organizational unlearning so far has received limited attention. Recently, Alam (2019) completed a systematic literature review on topic of unlearning and succeeded to identify only 26 papers related to the topic. Nevertheless, as organizational unlearning is crucial when organizations need to adapt to environmental changes and can enhance a firm's performance (Tsang \& Zahra, 2008), it should receive further attention from researchers.

\section{Marketing Knowledge Management}

While investigating the link between knowledge and marketing management, the database search indicated a quite new and not widely studied concept associated with market-related knowledge. Although research on Marketing Knowledge Management (MKM) is still very limited, with the growing prominence of marketing in contemporary business settings, there is a need for organizations to emphasis their MKM as it embodies opportunities of competitive success (Akroush \& Al-Mohammad, 2010). MKM refers to knowledge associated with organizational marketing processes, that is, with activities planned for the elaboration of marketing mix. MKM emerged as a new topic of investigation and despite its scarcity, it provides a starting-point for knowledge-marketing management inquirers. Definitely, the examination of existing marketing literature reveals that both external (customer-centered) and internal (focused on employees) 
market orientation theories have largely been constructed on KM perspective (Zebal et al., 2019). Therefore, marketing seeks for more specific terms relating it to knowledge. Akroush and AlMohammad (2010) defined MKM as "a discipline that involves the recognition and analysis of obtainable and required marketing-related knowledge assets and capabilities, and the ensuing planning and control of actions to develop both the marketing assets and capabilities so as to fulfill organizational objectives" (p.42). Correspondingly, marketing assets are the firm's resources developed over time and that can help positioning the organization in the marketplace. Relatedly, marketing capabilities are the skills and knowledge trained through organizational processes (Akroush \& Al-Mohammad, 2010). Internal brand management has in its scope the entire body of employees, who play a crucial role in increasing competitive advantage through strong branding (Burmann et al., 2009). Now parting from KM and organizational learning, the review will focus on topics related first to brand and then to internal brand management.

\section{Brand Management}

Branding is contemplated as fundamental not only positioning a product or service, but it also plays an important role in attracting and retaining talented employees. According to the Theurer (2018), employer brand is multidimensional and influenced by various factors consistent with organizational knowledge management. As employer branding is a strategy determined to create and support the understanding the employees (both current \& future) have about their organizational brand, it requires efficient knowledge dissemination skills. Correspondingly, an organization opened for learning will be more successful in building its brand's attractiveness and performance (Rampl \& Kenning, 2014). Effective brand management enables to increase the perceived value of a product or a brand (Aaker, 1991). The literature indicates three dominant views as it comes to brand management: (1) the widely studied customer-based perspective which examines the relationship between the brand and its customers; (2) the financial perspective; and the most recent; and (3) employee-based perspective which states that the success of the brand strategy depends on the role of employees. This study explores the third perspective of brand management and focuses on the employer brand.

\section{Employer Brand}

The discipline of employer branding has grown over passed years, as the organizations struggle to attract and maintain talented employees (Theurer, 2018). It is somewhat difficult to trace the origins of the concept, as it emerges mutually from the branding, human resources and relationship marketing literature (Tanward \& Prasad, 2017). Employer Brand (EB) was first defined by Ambler and Barrow (1996) as "the package of functional, economic and psychological benefits provided by employment and identified with the employing company" (p. 186). Later, Backhaus and Tikoo (2004) defined employer branding as "the process of building an identifiable and unique employer identity, and the employer brand as a concept of the firm that differentiates it from its competitors" (p. 502). With accordance to the Barrow and Mosely (2011) the aim of the employer brand is to improve the productivity and commitment to the company and can lead to achieve superior competitive advantage. Similarly, Tanward and Prasad (2017) described the employer brand as "a set of tangible and intangible benefits offered by the organization to attract potential employees and retain existing employees" (p. 392). 
One fact is undeniable, EB brings some additional benefits to the organizations. As postulated by many scholars, the organizations with strong employer brand get benefits such as: improved employee retention, reduced cost of employee acquirement, and superior employee relations (Berthon et al., 2005; Leekha et al., 2014). While compared to companies with weaker employer brands, they can also offer lower salaries without the risk of losing the capable stuff. In other study aimed at investigating the Millennials' perspective of brand attractiveness and the intentions to apply for a job, it was found that the economic factors (such as salary or job promotions) were less important than personal interest, fun work environment or recognition that the employer brand offers (Santiago, 2019). Accordingly, the EB attractiveness is crucial while competing for talented employees and, as EB enriches the organizational growth and leads to achieve superior performance (e.g., innovation), it should be taken into consideration while framing market strategies. Due to those premises, the employer branding become a strategic tool widely used by human resources for attracting and retaining employees (Tanward \& Prasad, 2017). The importance of EB is crucial mainly in the area of services, as the talented employees help the organization in delivering better service quality to the customers (Lush et al., 2007). Despite the growing interest, the EB literature still appears to be very fragmented, mainly due to the multidisciplinary and the wide scope of the phenomenon.

\section{Employer Brand Attractiveness and Talent Retention}

Effectively branding the employer can help the organization to attract talented employees (Rampl \& Kenning, 2014). They claimed that a brand can be attractive in the eyes of general public or customers, but also current and future employees. Indeed, also Punjaisri et al. (2008) noticed that EB is increasingly seen as a "guideline to ensure employees' delivery of the brand promise and it serves to shape employees' brand attitudes and behaviors" (p. 2). Accordingly, no firm can be prosperous without capable employees. As employees are a key element of knowledge transfer within an organization, also the facilitated learning within the organization is necessary.

Research has shown that employees consider the employer brand to be more attractive when the organization as a whole is perceived to be successful (Maxwell \& Knox, 2009). The more attractive an employer is perceived, it attains stronger brand equity and better performance (Berthon et al., 2005; Jiang \& Iles, 2011). Berthon et al. (2005) postulated that the employer attraction can be conveyed to perceptions of the employer brand value. According to Edwards (2010), "potential recruits are more likely to apply for a job at a particular organization that has an existing positive company reputation. The greater a company's reputation, the more attractive it tends to be to potential recruits" (p. 8). Despite the prominence of the subject, academic research on employer brand attractiveness reminds limited, whereas talent retention finds deeper investigation in the area of human resources.

\section{Brand Commitment}

Brand commitment was defined by Asha and Jyothi (2013) as "an extension of the employee's psychological link to the brand, which influences the desire to exert extra efforts to achieve the brand's goals" (p. 39). The level of the employees' commitment to the brand is essential in the willingness of the employees to deliver the brand promise and is an important dimension in understanding brand performance. In terms of brand commitment, prior literature offers several 
conceptualizations. Perhaps the most prominent conceptualization is Allen and Meyer (1990)'s explanation of 'affective', 'continuance', and 'normative' commitment. According to Allen and Meyer (1990), "employees with strong affective commitment remain because they want to, those with strong continuance commitment because they need to, and those with strong normative commitment because they feel they ought to do so" (p. 3). Accordingly, the affective commitment denotes to employees' relationship with the organization; whereas continuance and normative commitment imply the perceived costs of leaving the company or a commitment to stay (Allen \& Meyer, 1990). Contemplation of these peculiarities is essential, because organizations expect from employees more than merely alleged attachment (Meyer \& Allen, 1997). Fittingly, understanding an employee's intent to continue working for an organization is essential, as employees who are committed to stay and express the emotional attachment to the organizational brand, usually embody a positive brand behavior (King \& Grace, 2010). In recent studies, the development of models that provide an understanding of the process of building a powerful brand (mostly in the area of services) has emphasized the role of employee brand commitment and their contribution to enhance brand equity.

\section{Employee-Based Brand Equity}

Employee-Based Brand Equity (EBBE) results from the knowledge that the employee has about the brand of the organization for which s/he works, producing positive or negative behaviors, according to the objectives and promise of the brand to be communicated. It is pertinent for employees to deliver the brand promise, which allows the organization to generate competitive advantages in the market by delivering the service consistently while maintaining the identity and corporate image desired by the organization (Punjaisri \& Wilson, 2007). EBBE occurs when an employee has enough brand knowledge to execute a positive and productive brand-related behavior. Accurately, it focuses on the role of the employee in building the brand equity. EBBE not only provides the insights into how the organizations can effectively manage the internal brand building process, but also, into how to assess the subsequent organizational benefits. EBBE represents a new direction of the brand equity theories and extends the understanding of brand management (King \& Grace, 2010).

\section{Role Clarity}

Role clarity is defined as "the level of clarity an employee has of their role as a result of having brand knowledge" (King \& Grace, 2010, p.12). Role clarity enables employees to be given clear guidance by providing appropriate brand awareness (King \& Grace, 2009), which leads to a superior level of satisfaction and commitment. According to King and Grace (2005), the role of employees is a source of information for consumers because they are the interface between the brand and the outside world, ultimately influencing the way consumers perceive the brand. Therefore, it is essential that employee behavior should be consistent and reinforce the benefits that are communicated by the brand (Schneider \& Bowen, 1985). The effects of role clarity, along with its antecedents and consequences were usually investigated in the scope of employeeperceived service quality. It is not the first time that the concepts related to internal branding are found in the literature related to services. 


\section{Employee Engagement}

Employee engagement is defined as "the extent to which an individual is attentive and absorbed in the performance of his roles" (Saks, 2006, p. 600) and gained an academic attention as an important concept in organizational behavior (Hanaysha, 2016). Employee engagement represents a positive work-related behavior that can guide the performance outcomes. Engaged employees tend to be more productive and more profitable, enhancing customer satisfaction and loyalty. Previous research (e.g. Hanaysha, 2016; Schaufeli, 2012) suggested that work engagement affects the level of employees' organizational commitment. Recently, employee engagement has become a prominent subject among consulting firms. Nevertheless, it has rarely been studied in the academic literature, while the knowledge about its antecedents and consequences is still limited.

\section{Job Satisfaction}

Job satisfaction relates to the overall judgment an employee has about his job (Judge et al., 2017; Williams \& Anderson, 1991), and is defined as a level of satisfaction an employee has from the job and is based on the perceptions of the job value (Cammann et al., 1979). The concept of job satisfaction is similar to the concept of commitment - if an employee is committed to a job and feels fulfilled, it should lead to maintaining effort toward the job. Interestingly, commitment is predicted to rise with the passage of time, when an employee goes through a process of developing identification of the work role, whereas according to Judge et al. (2017), "one can be satisfied with a job's features very early on, even if not committed to the job until later" (p. 2).

There is a considerable interest in job satisfaction and the topic appears often in the human resources literature. One of the most cited articles found is a study by Locke (1969) entitled "What is job satisfaction?", which presented a conceptual approach. One of the oldest studies that were found dated from 1935 and was presenting results of a questionnaire and interviews on job satisfaction. This old study was exposing data on 500 teachers who estimated the degree of satisfaction with their jobs, while denoted association between job satisfaction and emotional adjustment, social status, interest, age, fatigue, religion, size of community, as well as other factors (Hoppock, 1935).

\section{Organizational Commitment}

As employees are the foundation for superior organizational performance, building organizational commitment is crucial for all organizations (Hanaysha, 2016). Organizational commitment focuses on the relationship the employees have with their organizations that reduces the turnover intention and is defined by Mowday et al. (1982) as:

The relative strength of an individual's identification with and involvement in a particular organization and can be characterized by a strong belief in and acceptance of the organization's goals and values, willingness to exert considerable effort on behalf of the organization and a strong desire to maintain membership of the organization. (p. 27)

Organizational commitment, expressed by having highly committed employees, is considered an indicator of employee loyalty and can lead to greater productiveness and performance. Relatively, few studies have focused on employee's organizational commitment. Normally, the topic is 
investigated within the area of corporate social responsibility and described in the light of effects that it has on corporate financial performance or the customer behavior.

\section{Organizational and Brand Performance}

For organizations to support the development of KM, they need confirmation that, as a consequence, it will improve their financial performance (Darroch, 2005). Although business performance is multi-dimensional, business success is largely associated with brand performance (DeChernatony \& Christodoulides, 2004). According to Harris et al. (2001), organizational and brand performance are two distinct, yet closely related dimensions. Organizational brands are important in achieving organization's success and help to generate competitive advantages. Brand performance can be considered as the attainment of organizational goals in the marketplace. Harris et al. (2001) defined brand performance as "the relative measurement of the brand's success in the marketplace" (p. 445). The setting of learning organization should keep an emphasis on both individuals and departments, that would lead to achieve superior brand performance. Consequently, Harris et al. (2001) stated that "corporate branding requires a holistic approach to brand management, in which all members of an organization behave according to the desired brand identity" (p. 442). Corporate branding requires a different management attitude than product line branding. It integrates the internal activities to guarantee consistency in brand delivery and approaches the role of employees in the brand building (Balmer et al., 2001). Due to those advances, the role of employees is changing, and they start to be perceived as brand's ambassadors who have a meaningful impact on consumers' perceptions (Hemsley, 1998).

\section{The Proposed Conceptual Model Linking Knowledge and Brand Management}

The findings from the literature summarized above are integrate into the proposed conceptual

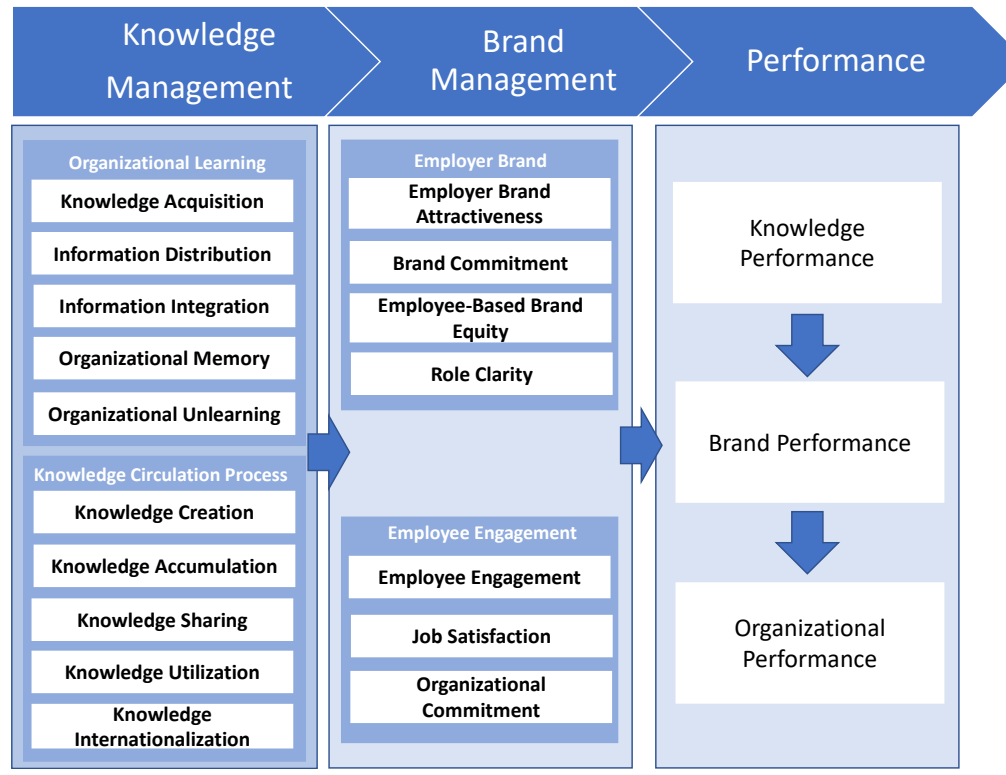

Figure 1. The Proposed Knowledge-Brand-Performance (KBP) Model based on Theurer et al. (2018) 
(Knowledge-Brand-Performance) KBP model, linking the processes of knowledge and brand management - specifically the employer brand management (See Figure 1). The new model proposed here is inspired by "employer branding value chain model" proposed by Theurer et al. (2018) but adds from the field of KM and is grounded in a completely distinct literature review

\section{The Relationship Between Knowledge Management and Employer Branding}

It has been widely acknowledged that knowledge is critical to firm success, particularly for firms operating in the area of services. On one side, organizational branding demands greater emphasis on factors internal to the organization, therefore, is should focus greater attention to the role of employees in the brand building process (Harris et al., 2001). On the other side, employer brand management, as a consequence of internal branding, is augmented by employees' knowledge of brand (King \& Grace, 2010). KM helps employees comprehend the brand strategy and the reasoning behind management decisions. Employees who acquire brand related information, incline to move from merely understanding their function, to unveiling a strong loyalty and commitment to the organization (King \& Grace, 2010). They also start to perceive the organizational brand as more attractive and the organization itself becomes a more attractive place to work for. It is also argued here that organizations, who chase knowledge are more likely to retain strong brand performance. The essential rationale motivating this statement, is that the employee perception of the employer brand is one of the most important assets, that the company should aim at while setting the internal brand strategy (Darroch, 2005).

\section{Directions for Future Research}

It is expected that the future research is pursued and will draw nearer to understanding the relation between KM and employer brand management. The direction for future research relays on the limitations of this study. The main limitation resists in its conceptual and narrative character. It would be a complex task to undertake future systematic review due to the multidimensionality of the concepts under study. Still, a systematic review could bring a more complete list of the concepts and variables related to both knowledge and brand management. Such a study could also bring more light on marketing knowledge management where the evidence is still scarce. A future empirical study would be essential to show evidence support for the proposed conceptual framework and state particular research propositions. For this purpose, primary a qualitative research may be conducted to provide more insights and to check the suitability of the linkage of the different perspectives used in the model. Then, future research may also use a quantitative study to empirically test the associated propositions. It would be crucial to get the data from specific industries and companies, particularly the ones operating in services (as the employees are the key element to build the organizational brand).

\section{Conclusions}

Linking it altogether, the knowledge and brand management processes start with the organizational learning and knowledge circulation should aim at the employees as well as their knowledge regarding the employer brand and role clarity. Then, moving into the employee's perceptions and 
actions: employer brand attractiveness will most probably have an impact on their commitment and job satisfaction, influencing the perceived employee-based brand equity. Finally, the process will result in bringing the value to the organizations in form of knowledge and brand performance.

This study makes an important academic contribution by combining the KM, organizational learning, and brand management. Considering the importance of employees as providers of customer experience, especially in the specific area of services, the objective of knowledge and brand management is to guarantee that employees represent brand messages (persist brand-related behavior) in a way that consumers and other stakeholders can perceive. Satisfied employees have a better understanding of the organizational goals and perceive the organizational brand as more attractive. They represent a certain level of commitment, so important for the overall success of the organization. Employer brand management is considered an effective tool for the creation and maintenance of strong brands. It is also considered as difficult to copy or replicate by the competition. However, only the employees who have the access to organizational knowledge will have the full understanding of the organizational brand. Therefore, moving the right knowledge to the right people is essential and only with the right level of knowledge circulation and facilitated learning, the employees will have the right vision of their organizational brand.

\section{References}

Abrams, D. E., \& Hogg, M. A. (1990). Social identity theory: Constructive and critical advances. Springer-Verlag Publishing.

Akroush, M. N., \& Al-Mohammad, S. M. (2010). The effect of marketing knowledge management on organizational performance. International Journal of Emerging Markets, 5(1), 38-77.

Alam, S.A.N. (2019). Managing organizational knowledge by unlearning? A systematic literature review. Proceedings of the International Conference on Computational Intelligence and Knowledge Economy, 81-86.

Allen, N. J., \& Meyer, J. P. (1990). The measurement and antecedents of affective, continuance and normative commitment to the organization. Journal of Occupational Psychology, 63(1), $1-18$.

Ambler, T., \& Barrow, S. (1996). The employer brand. Journal of Brand Management, 4(3), 185206.

Asha, C. S., \& Jyothi, P. (2013). Internal branding: A determining element of organizational citizenship behaviour. Journal of Contemporary Management Research, 7(1), 37-57.

Backhaus, K.B. \& Tikoo, S. (2004). Conceptualizing and researching employer branding. Career Development International, 9, 501-517.

Balmer, J. M., Harris, F., \& de Chernatony, L. (2001). Corporate branding and corporate brand performance. European Journal of Marketing, 35(3/4), 441-456.

Barney, J. A. (1991). Firm resources and sustained competitive advantage. Journal of Management, 17(1), 99-120. 
Barney, J. B. (2001). Resource-based theories of competitive advantage: A ten-year retrospective on the resource-based view. Journal of Management, 27(6), 643-650.

Barrow, S., \& Mosley, R. (2011). The employer brand: Bringing the best of brand management to people at work. John Wiley \& Sons.

Berthon, P., Ewing, M., \& Hah, L. L. (2005). Captivating company: dimensions of attractiveness in employer branding. International Journal of Advertising, 24(2), 151-172.

Burmann, C., Zeplin, S., \& Riley, N. (2009). Key determinants of internal brand management success: An exploratory empirical analysis. Journal of Brand Management, 16(4), 264-284.

Cammann, C., Fichman, M., Jenkins, D., \& Klesh, J. (1979). The Michigan organizational assessment questionnaire. Unpublished manuscript, University of Michigan: Ann Arbor.

Cabrera-Suárez, K., De Saá-Pérez, P., \& García-Almeida, D. (2001). The succession process from a resource-and knowledge-based view of the family firm. Family Business Review, 14(1), $37-48$.

Cha, H. S., Pingry, D. E., \& Thatcher, M. E. (2008). Managing the knowledge supply chain: An organizational learning model of information technology offshore outsourcing. Management Information Systems Quarterly, 32(2), 281-306.

Chen, C. J., \& Huang, J. W. (2007). How organizational climate and structure affect knowledge management-The social interaction perspective. International Journal of Information Management, 27(2), 104-118.

Chirico, F., \& Salvato, C. (2016). Knowledge internalization and product development in family firms: When relational and affective factors matter. Entrepreneurship Theory and Practice, 40(1), 201-229.

Coopey, J. (1995). The learning organization, power, politics and ideology introduction. Management Learning, 26(2), 193-213.

Cronin, P., Ryan, F., \& Coughlan, M. (2008). Undertaking a literature review: A step-by-step approach. British Journal of Nursing, 17(1), 38-43.

Cyert, R.M. \& March, J.G. (1963). A behavioral theory of the firm. Prentice Hall.

Darroch, J. (2005). Knowledge management, innovation and firm performance. Journal of Knowledge Management, 9(3), 101-115.

Dimitriades, Z. S. (2005). Creating strategic capabilities: Organizational learning and knowledge management in the new economy. European Business Review, 17(4), 314-324.

Duncan, W. J. (1972). The knowledge utilization process in management and organization. Academy of Management Journal, 15(3), 273-287.

Duncan, R., \& Weiss, A. (1979). Organizational learning: Implications for organizational design. Research in Organizational Behavior, 1, 75-123.

Edmondson, A., \& Moingeon, B. (1996). When to learn how and when to learn why: Appropriate organizational learning processes as a source of competitive advantage. Sage Publications. 
Edwards, M. R. (2010). An integrative review of employer branding and OB theory. Personnel Review, 39(1), 5-23.

Fiol, C., \& Lyles, M. (1985). Organizational learning. Academy of Management Review, 10, 803813.

Fraj, E., Matute, J., \& Melero, I. (2015). Environmental strategies and organizational competitiveness in the hotel industry: The role of learning and innovation as determinants of environmental success. Tourism Management, 46, 30-42.

Garratt, B. (1987). The learning organization. Fontana.

Gillani, S. H. M., \& Kiani, M. N. (2018). Organizational learning processes as predecessor of organizational effectiveness: Conditional process analysis. Asia Proceedings of Social Sciences, 2(3), 132-136.

Grant, R. M. (1991). The resource-based theory of competitive advantage: Implications for strategy formulation. California Management Review, 33(3), 114-135.

Hanaysha, J. (2016). Testing the effects of employee engagement, work environment, and organizational learning on organizational commitment. Procedia-Social and Behavioral Sciences, 229, 289-297.

Harris, F., \& De Chernatony, L. (2001). Corporate branding and corporate brand performance. European Journal of Marketing, 35(3/4), 441-456.

Hedberg, B.L.T. (1981). How organizations learn and unlearn. In Nystrom, P. C., \& Starbuck, W. H. (Eds.), Handbook of organizational design. Volume I. Oxford University Press.

Hemsley, S. (1998). Internal affairs. Marketing Week, 2(49-50), 53.

Hoppock, R. (1935). Job satisfaction. Harper. https://psycnet.apa.org/record/1936-00559-000

Huber, G. P. (1991). Organizational learning: The contributing processes and the literatures. Organization Science, 2(1), 88-115.

Imai, K., Nonaka, I., \& Takeuchi, H. (1984). Managing the new product development process: How Japanese companies learn and unlearn. Division of Research, Harvard Business School.

Imran, M. K., Ilyas, M., \& Aslam, U. (2016). Organizational learning through transformational leadership. The Learning Organization, 23(4), 232-248.

Jiang, T., \& Iles, P. (2011). Employer-brand equity, organizational attractiveness and talent management in the Zhejiang private sector, China. Journal of Technology Management in China, 6(1), 97-110.

Judge, T. A., Weiss, H. M., Kammeyer-Mueller, J. D., \& Hulin, C. L. (2017). Job attitudes, job satisfaction, and job affect: A century of continuity and of change. Journal of Applied Psychology, 102(3), 356-374.

King, C., \& Grace D., (2005). Exploring the role of employees in the delivery of the brand: A case study approach. Qualitative Market Research: An International Journal, 8(3), 277-295. 
King, C., \& Grace D., (2009). Employee based brand equity: A third perspective. Services Marketing Quarterly, 30(2), 122-147.

King, C., \& Grace D., (2010). Building and measuring employee based brand equity. European Journal of Marketing, 44, 938-971.

Klein, G. (1989). Parenthetic learning in organizations: Toward the unlearning of the unlearning model. Journal of Management Studies, 26, 291-308.

Korte, R. F. (2007). A review of social identity theory with implications for training and development. Journal of European Industrial Training, 31(3), 166-180.

Lee, K. C, Lee, S., \& Kang, W. (2005). KMPI: Measuring knowledge management performance. Information \& Management, 42(3), 469-482.

Leekha C., N., \& Sharma, S. (2014). Employer branding: Strategy for improving employer attractiveness. International Journal of Organizational Analysis, 22(1), 48-60.

Locke, E. A. (1969). What is job satisfaction? Organizational Behavior and Human Performance, 4(4), 309-336.

March, J. G., \& Olsen, J. P. (1975). The uncertainty of the past: Organizational learning under ambiguity. European Journal of Political Research, 3(2), 147-171.

Meyer, J. P., \& Allen, N. J. (1997). Commitment in the workplace: Theory, research, and application. Sage Publications.

Maxwell, R., \& Knox, S. (2009). Motivating employees to "live the brand" : A comparative case study of employer brand attractiveness within the firm. Journal of Marketing Management, 25(9/10), 893-907.

McDermott, R., \& O’Dell, C. (2001). Overcoming cultural barriers to sharing knowledge. Journal of Knowledge Management, 5(1), 76-85.

Mowday, R. T., Porter, L. W., \& Steers, R. (1982). Organizational linkages: The psychology of commitment, absenteeism, and turnover. Academic Press.

Namada, J. M. (2018). Organizational learning and competitive advantage. In Handbook of Research on Knowledge Management for Contemporary Business Environments (86-104). IGI Global.

Nicolini, D., \& Meznar, M. B. (1995). The social construction of organizational learning: conceptual and practical issues in the field. Human Relations, 48(7), 727-746.

Nonaka, I. (1994). A dynamic theory of organizational knowledge creation. Organization Science, 5(1), 14-37.

Nonaka, L., Takeuchi, H., \& Umemoto, K. (1996). A theory of organizational knowledge creation. International Journal of Technology Management, 11(7-8), 833-845.

Nonaka, I., \& Toyama, R. (2015). The knowledge-creating theory revisited: Knowledge creation as a synthesizing process. In The essentials of knowledge management (95-110). Palgrave Macmillan. 
North, K., \& Kumta, G. (2018). Knowledge management: Value creation through organizational learning. Springer.

O'Dell, C., \& Grayson, C. J. (1998). If only we knew what we know: Identification and transfer of internal best practices. California Management Review, 40(3), 154-174.

Organ, D. W. (1997). Organizational citizenship behavior: It's construct clean-up time. Human Performance, 10(2), 85-97.

Pedler, M., Burgoyne, J., \& Boydell, T. (1991). The learning company. A strategy for sustainable development. McGraw-Hill.

Pedler, M., \& Burgoyne, J. G. (2017). Is the learning organisation still alive? The Learning Organization, 24(2), 119-126.

Pemberton, J. D., \& Stonehouse, G. H. (2000). Organisational learning and knowledge assets - an essential partnership. The Learning Organization, 7(4), 184-194.

Pertusa-Ortega, E. M., Zaragoza-Sáez, P., \& Claver-Cortés, E. (2010). Can formalization, complexity, and centralization influence knowledge performance? Journal of Business Research, 63(3), 310-320.

Postrel S. (2002). Islands of shared knowledge: Specialization and mutual understanding in problem-solving teams. Organization Science, 13(3), 303-320.

Punjaisri, K., Wilson, A., (2007). The role of internal branding in the delivery of employee brand promise, Journal of Brand Management, 15(1), 57-70.

Punjaisri, K., Wilson, A., \& Evanschitzky, H. (2008). Exploring the influences of internal branding on employees' brand promise delivery: Implications for strengthening customer-brand relationships. Journal of Relationship Marketing, 7(4), 407-424.

Rampl, V. L., \& Kenning, P. (2014). Employer brand trust and affect: Linking brand personality to employer brand attractiveness. European Journal of Marketing, 48(1/2), 218-236.

Saks, A. M. (2006). Antecedents and consequences of employee engagement. Journal of Managerial Psychology, 21(7), 600-619.

Santiago, J. (2019). The relationship between brand attractiveness and the intent to apply for a job: A millennials' perspective. European Journal of Management and Business Economics. https://doi.org/10.1108/EJMBE-12-2018-0136

Schaufeli, W. (2012). Work engagement: An emerging psychological concept. Proceedings of the 30th International Congress on Occupational Health.

Schneider, B., \& Bowen, D. (1985). Employee and customer perceptions of service in banks: Replication and extension. Journal of Applied Psychology, 70, 423-433.

Storey C., \& Kahn, K. B. (2010). The role of knowledge management strategies and task knowledge in stimulating service innovation. Journal of Service Research, 13(4), 397-410.

Swanson, R. A., Holton, E., \& Holton, E. F. (2001). Foundations of human resource development. Berrett-Koehler Publishers. 
Szulanski, G. (1996). Exploring internal stickiness: Impediments to the transfer of best practice within the firm. Strategic Management Journal, 17(S2), 27-43.

Tajfel, H. (1970). Experiments in intergroup discrimination. Scientific American, 223, 96-102.

Tajfel, H., Turner, J. C., Austin, W. G., \& Worchel, S. (1979). An integrative theory of intergroup conflict. Organizational Identity: A reader, 56(65), 33-47.

Tanwar, K., \& Prasad, A. (2017). Employer brand scale development and validation: A secondorder factor approach. Personnel Review, 46(2), 389-409.

Teece, D. J., Pisano, G., \& Shuen, A. (1997). Dynamic capabilities and strategic management. Strategic Management Journal, 18(7), 509-533.

Theurer, C. P., Tumasjan, A., Welpe, I. M., \& Lievens, F. (2018). Employer branding: A brand equity-based literature review and research agenda. International Journal of Management Reviews, 20(1), 155-179.

Tsang, E. W., \& Zahra, S. A. (2008). Organizational unlearning. Human Relations, 61(10), 14351462.

Weber, A. L. (1991). HarperCollins college outline introduction to psychology. HarperCollins.

Williams, L. J., \& Anderson, S. E. (1991). Job satisfaction and organizational commitment as predictors of organizational citizenship and in-role behaviors. Journal of Management, 17(3), 601-617.

Zebal, M., Ferdous, A., \& Chambers, C. (2019). An integrated model of marketing knowledge - a tacit knowledge perspective, Journal of Research in Marketing and Entrepreneurship, 21(1), 2-18. https://doi.org/10.1108/JRME-03-2018-0018

\section{Author Biography}

Joanna K. Santiago joined Universidade de Lisboa, ISEG - School of Economics and Management in September 2014 and in 2018 she was also invited to join VIVES University of Applied Sciences at KU Leuven Association. Presently she is associated with both schools and frequently participates in International Exchange Programs across Europe. Her research focuses on knowledge and brand management, customer and employee-based perspective of brand equity and employer branding. She has a solid background in market

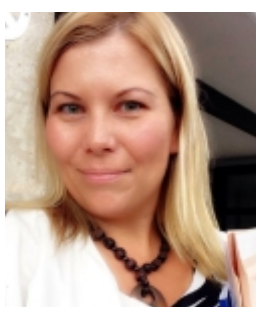
research and for more than ten years was working in the market research projects held at the top Portuguese schools of business and economics: ISCTE, Nova SBE, Catholic University and ISEG with the participation of Portuguese Foundation for Science and Technology (FCT) and European Commission. She organized a series of Art Management workshops co-oriented by Copenhagen Business School (CBS) as a fellow member of Studio at CBS, a group that helps executives, students, and faculty to develop wider repertories of thought and action, so called "creative thinking". She is also a strategy and image consultant who enjoys working with practitioners and artists. 